Diabetologia 8, 153-159(1972)

(C) by Springer-Verlag 1972

\title{
ORIGINALS
}

\section{Effects of Postnatal Feeding on the Functional Maturation of Pancreatic Islet B-Cells of Neonatal Rats}

\author{
K. Asplund \\ Histological Department, University of Uppsala, Uppsala, Sweden \\ Received: August 7, 1971, accepted: December 23, 1971
}

\begin{abstract}
Summary. The insulin response to glucose stimulation has been investigated in vivo and in vitro in suckling rats from small or large litters. In two day old animals from small litters there was a marked increase in serum insulin levels after an intraperitoneal glucose injection, while the insulin response to glucose in animals from large litters was low and sluggish. The weak insulin response to glucose in the two day old rats from large litters was further substantiated in studies in vitro in which the insulin release of isolated pancreatic glands was measured after incubation in a low or a high glucose concentration. On the third and fourth postnatal days there was an increased insulin secretion in response to the glucose challenge both in vivo and in vitro in the two groups of animals. The results indicate that postnatal feeding modulates the development of the glucose-mediated insulin release.
\end{abstract}

Effet de la nutrition post-natale sur la maturation fonctionnelle des cellules $B$ des îlots pancréatiques chez le rat nouveau-né

Résumé. La réponse de l'insuline à une stimulation par le glucose a été étudiée in vivo et in vitro chez des rats nouveau-nés de petites ou de grandes portées. Chez les animaux des petites portées, âgés de deux jours, il y avait une nette augmentation des taux de l'insuline du sérum après une injection de glucose intrapéritonéale, tandis que la réponse de l'insuline au glucose était faible et lente chez les animaux des grandes portées, âgés de deux jours. La faible réponse de l'insuline au glucose chez les animaux des grandes portées, âgés de deux jours, a été confirmée par l'étude in vitro dans laquelle a été mesurée la sécrétion d'insuline par les glandes pancréatiques isolées après incubation dans une concentration faible ou forte de glucose. Le $3^{\mathrm{e}}$ ou le $4^{\mathrm{e}}$ jour après la naissance, il y a une augmentation de la sécrétion d'insuline en réponse à une charge de glucose in vivo et in vitro dans les deux groupes d'animaux. - Les résultats indiquent que la nutrition post-natale influence le développement de la sécrétion d'insuline provoquée par le glucose. La possibilité d'une influence des facteurs extra-pancréatiques sur le procédé de maturation est discutée.

Die Wirkung der postnatalen Fülterung auf die funktionelle Reifung der B-Zellen der Pankreasinseln neonataler Ratten

Zusammenfassung. Die Insulinsekretion nach Glucosestimulation wurde in vivo und in vitro an kleinen und großen Würfen säugender Ratten untersucht. Bei 2 Tage alten Tieren aus kleinen Würfen war ein starker Anstieg des Seruminsulinspiegels nach intraperitonealer Glucoseinjektion festzustellen, während die Insulinantwort auf Glucose bei Tieren eines großen. Wurfs langsam und gering war. Die schwache Insulinsekretion nach Glucose bei 2 Tage alten Ratten eines großen Wurfs wurde in vitro weiter untersucht und die Insulinsekretion in geringer und hoher Glucosekonzentration gemossen. Am dritten und vierten postnatalen Tag wurde eine erhöhte Insulinsekretion in vivo und in vitro bei beiden Tiergruppen beobachtet. Die Ergebnisse deuten darauf hin, daß die Entwicklung der glucoseinduzierten Insulinsekretion von der postnatalen Fütterung beeinflußt ist.

Key words: Insulin content, pancreatic weight, glucose load, serum insulin, insulin release in vitro, neonatal period, postnatal feeding.

\section{Introduction}

In the foetus and newborn of several species the stimulating action of glucose on insulin secretion is poorly developed or absent $[1,2,6,7,24,25,29,32]$. This has been thoroughly investigated in the rat, in which studies both in vivo [2] and in vitro $[2,6]$ have shown a lack of insulin secretory response to glucose up to the second postnatal day. This does not seem to depend on a general immaturity of the B-cell, since foetal B-cells incubated in medium containing both glucose and theophylline show a marked increase in insulin release $[26,28]$. On the basis of these and other observations it has been suggested that a decreased level of cyclic [3', 5'] AMP in the fetal B-cell may be the cause of the insensitivity to glucose [28].

It is not known to what extent the neonatal function of the B-cell depends on extrapancreatic factors.
In the rat, a shift to a glucose-sensitive type of insulin secretory mechanism occurs during the first days of extrauterine life $[2,6]$. It is therefore possible that the feeding during early neonatal life influences the maturation process of the B-cell, either through changes of the blood glucose levels or through an effect on the release of certain hormones. The present study is an attempt to determine whether the development of the insulin responsiveness of the $\mathrm{B}$-cells to glucose is related to the caloric intake of the newborn rat.

\section{Animals Materials and Methods}

The offspring of Sprague-Dawley rats (obtained from Anticimex, Stockholm, Sweden) were used throughout this study. Pregnant and lactating mothers were reared under uniform conditions and were allowed 
free access to commercial pelleted food (Anticimex, Stockholm, Sweden). The mothers gave birth to litters containing $7-13$ animals with a mean body weight of $6.5+0.1 \mathrm{~g}$ (S. E. M. ; $n=34$ ).

In order to achieve marked variations in their caloric intake, the newborn rats were grouped into litters of various sizes according to the following technique.

Within $10 \mathrm{~h}$ of delivery the offspring of $2-3$ mothers were collected and randomly regrouped into small litters (SL) with $\mathbf{5}$ animals, and large litters (LL) with 15-20 animals in each. The litters were then immediately returned to the mothers.

The investigations were performed on two, three and four day old rats, i.e. $36-60 \mathrm{~h}, 60-84 \mathrm{~h}$, and $84-108 \mathrm{~h}$ after delivery. The animals were allowed to suckle at will from birth until $2 \mathrm{~h}$ before the start of the experiment, when they were separated from the mothers and kept at an ambient temperature of $+32^{\circ}$ to $+34^{\circ} \mathrm{C}$. cubation medium, weighed and transferred without slicing to Warburg vessels (total volume $5-6 \mathrm{ml}$ ) for incubation. The incubation medium consisted of KrebsRinger phosphate-buffered salt solution [38] supplemented with $2 \mathrm{mg} / \mathrm{ml}$ bovine plasma albumin and $5 \mathrm{mM}$ each of pyruvate, glutamate and fumarate [12]. Glucose was added to the medium at a concentration of 0.6 or $3.0 \mathrm{mg} / \mathrm{ml}$.

The pancreatic glands were incubated individually at $+37^{\circ} \mathrm{C}$ with constant shaking (108 strokes per min) in a gas phase of pure oxygen. The incubation procedure was similar to that described by Coore and Randle [12]. After preincubation for $30 \mathrm{~min}$ at the low glucose concentration, the glands were rinsed in fresh medium, transferred to new vessels and incubated for a further $30 \mathrm{~min}$ period in $0.5 \mathrm{ml}$ of medium containing $0.6 \mathrm{mg}$ glucose $/ \mathrm{ml}$. This was followed by a final incubation period of $30 \mathrm{~min}$ in medium with a glucose concentration of $3.0 \mathrm{mg} / \mathrm{ml}$. Samples of the incubation

Table 1. Wet weight and insulin content of the pancreas of newborn rats from small (SL) and large litters (LL). Mean $\pm S E M$. The number of observations are given within parentheses. Insulin content values are not corrected for loss of insulin during the extraction procedure

\begin{tabular}{|c|c|c|c|c|c|c|c|c|c|}
\hline \multirow[t]{2}{*}{$\begin{array}{l}\text { Age } \\
\text { (days) }\end{array}$} & \multicolumn{3}{|c|}{$\begin{array}{l}\text { Pancreas weight } \\
\text { (mg) }\end{array}$} & \multicolumn{3}{|c|}{$\begin{array}{l}\text { Pancreatic insulin content } \\
(\mu \mathrm{g} / \mathrm{mg})\end{array}$} & \multicolumn{3}{|c|}{$\begin{array}{l}\text { Total pancreatic insulin content } \\
\text { (ug/pancreas) }\end{array}$} \\
\hline & $\mathrm{SL}$ & $\mathrm{LL}$ & SL VS LL & SL & $\mathrm{LL}$ & SL vs LL & SL & $\mathrm{LL}$ & SL vs LL \\
\hline 2 & $\begin{array}{l}30.7 \pm 1.3 \\
(6)\end{array}$ & $\begin{array}{l}29.5 \pm 1.0 \\
(10)\end{array}$ & n.s. & $\begin{array}{l}0.42 \pm 0.02 \\
(6)\end{array}$ & $\begin{array}{l}0.28 \pm 0.02 \\
(10)\end{array}$ & $P<0.001$ & $\begin{array}{l}13.1 \pm 0.9 \\
(6)\end{array}$ & $\begin{array}{l}8.3 \\
(10)\end{array} 0.5$ & $P<0.001$ \\
\hline 3 & $\begin{array}{l}36.7 \pm 1.5 \\
(9)\end{array}$ & $\begin{array}{l}35.9 \pm 3.0 \\
(7)\end{array}$ & n.s. & $\begin{array}{l}0.37 \pm 0.02 \\
(9)\end{array}$ & $\begin{array}{l}0.27 \pm 0.02 \\
(7)\end{array}$ & $P<0.01$ & $\begin{array}{l}13.7 \pm 0.8 \\
(9)\end{array}$ & $\begin{array}{l}9.6 \pm 0.6 \\
(7)\end{array}$ & $P<0.01$ \\
\hline 4 & $\begin{array}{l}42.1 \pm 1.7 \\
(8)\end{array}$ & $\begin{array}{l}32.6 \pm 2.9 \\
(6)\end{array}$ & $P<0.05$ & $\begin{array}{l}0.40 \pm 0.04 \\
(8)\end{array}$ & $\begin{array}{l}0.38 \pm 0.05 \\
(6)\end{array}$ & n.s. & $\begin{array}{l}16.9 \pm 2.2 \\
(8)\end{array}$ & $\begin{array}{l}11.7 \pm 0.6 \\
(6)\end{array}$ & n.s. \\
\hline
\end{tabular}

\section{Administration of glucose in vivo}

After the animals had been weighed, a 10 per cent sterile glucose solution was injected intraperitoneally at a dose of $2.0 \mathrm{~g} / \mathrm{kg}$ body weight. To prevent leakage at the site of injection, vaseline was applied around the hypodermic needle before withdrawal. At intervals of 15,30 and $60 \mathrm{~min}$ after the glucose injection, animals were bled to death by cutting the neck vessels, and the blood was collected in dry test tubes. The samples were put on ice and after coagulation the serum was separated by centrifugation and stored frozen for subsequent insulin and glucose determinations. Blood samples were also taken from control animals (no injection) in the same litters for determination of basal serum insulin and glucose levels.

The injection procedure did not appear to affect serum glucose or serum insulin levels, since in animals injected with 0.9 per cent saline and in control animals (no injection) there was no difference in serum insulin or glucose levels measured at the post-injection time intervals.

\section{Incubation of pancreatic glands in vitro}

Animals were killed by decapitation and the pancreatic glands quickly excised, rinsed in cold in- fluid from the last two incubation periods were immediately frozen and stored at $-20^{\circ} \mathrm{C}$ for subsequent insulin determinations.

The degradation of insulin during the incubations was estimated in separate experiments as described by Mirsky et al. [30]. The recovery of ${ }^{125} \mathrm{I}$-insulin added to the incubation medium was found to be $75 \pm 2$ per cent $(n=12)$ in each of the last two $30 \mathrm{~min}$ incubation periods. No differences in insulin degradation were found with pancreatic tissue from animals of different neonatal ages.

\section{Measurements of insulin and serum glucose}

Insulin determinations on serum or incubation media were performed with the double antibody radioimmunoassay of Hales and Randle [22].

${ }^{125}$ I-insulin and insulin binding reagent were obtained from The Radiochemical Centre, Amersham, England. Crystalline mouse insulin and crystalline rat insulin were generously provided by Dr. J. Schlichtkrull, Novo Research Institute, Copenhagen, Denmark. Bovine plasma albumin. (Fraction V) was a product of Armour Pharmaceutical Co., Eastbourne, England. Crystalline mouse insulin was used for standards, since it was found to have a similar cross-reactivity as 
crystalline rat insulin with the commercial antibody preparation. Duplicate determinations were performed on each sample, the error for a single determination being \pm 11 per cent.

Serum glucose levels were assayed on 5 ul duplicate samples by the glucose oxidase method of Hjelm \& De Verdier [23]. The error for a single determination was calculated as \pm 4 per cent.

\section{Extraction of insulin}

Rats were sacrificed without preceding fasting and the pancreas removed together with the gut. Each pancreatic gland was then dissected out in its entirety, weighed and immediately subjected to the extraction procedure.

Insulin was extracted by a modification of the acid ethanol technique described by Scott and Fisher [35]. The pancreatic tissue was homogenized in a glass tissue grinder with $1.0 \mathrm{ml}$ acid ethanol (75 ethanol: $25 \mathrm{H}_{2} \mathrm{O}: 1.5$ conc $\mathrm{HCl}, \mathrm{v} / \mathrm{v}$ ). The homogenizer was rinsed twice with $0.5 \mathrm{ml}$ acid ethanol and the three portions of extraction fluid were pooled and allowed to stand with the homogenized pancreas at $+4^{\circ} \mathrm{C}$ for $24 \mathrm{~h}$. The homogenate was then centrifuged and the supernatant was transferred to a plastic tube and stored at $-20^{\circ} \mathrm{C}$ until assayed for insulin content. The efficiency of the extraction procedure was estimated by addition of ${ }^{125}$ I-insulin to the first portion of the extraction fluid before the homogenization. The recovery of radioactive insulin was estimated to be $90 \pm 1$ per cent $(n=7)$.

\section{Statistical methods}

The results have been expressed as the mean $t$ standard error of the mean (S.E.M.). The data were subjected to a test of significance using Student's $t$-test and differences were considered significant when $P<0.05$. Method errors were calculated according to Dahlberg's formula [16].

\section{Body weights}

\section{Results}

As shown in Fig. 1 the SL animals were already significantly heavier than the LL animals on the second postnatal day $(P<0.001)$. The difference between the weights increased during the subsequent period of observation, the average weight ratio of SL to LL rats being $1.2,1.3$, and 1.5 at two, three and four days of age, respectively. It was notable that there was no further weight gain of the IL animals between three and four days of age.

\section{Pancreatic weight and insulin content}

As shown in Table 1 similar pancreatic weights were recorded in the two groups of animals at two days of age. There was a progressive increase of pancreatic weight in the SL group up to four days of age, while the LL rats showed no significant increase during this period. At four days of age there was a significant difference in pancreatic weights between SL and LL animals $(P<0.05)$.

During the observation period there was no change in the insulin content per $\mathrm{mg}$ pancreas of the SL animals, whereas in the LL group a significant increase $(P<0.05)$ was recorded between three and four days of age. Two and three day old SL animals displayed higher insulin content per mg pancreas than the corresponding LL groups. At four days of age this difference had disappeared.

The total pancreatic insulin content was significantly higher in the SL than in the LL animals both on the second and the third postnatal day. An increase in total insulin content during the observation period was recorded in both groups of animals.

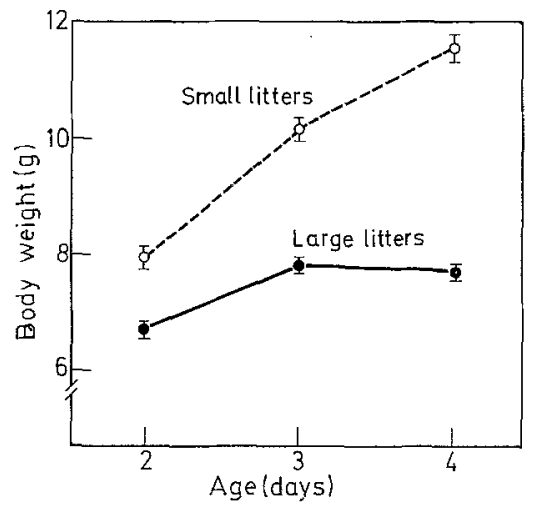

Fig. 1. Body weights in neonatal rats from small $(0 \ldots . .$. and large litters (- $)$ at different ages. Mean values \pm SEM

\section{Basal serum insulin and glucose levels}

The serum glucose concentration of the rats, shown at zero time in Figs. 2-4, gradually increased with age. In the two day old rats of the SL group the glucose concentration was $69 \pm 5 \mathrm{mg} / 100 \mathrm{ml}$. rising to $93 \pm 6 \mathrm{mg} / 100 \mathrm{ml}$ in the four day old animals $(P<0.01)$. A similar rise was noted in the LL animals, in which the serum glucose concentration in the two day old rats was $54 \pm 3 \mathrm{mg} / 100 \mathrm{ml}$ and in the four day old animals $77 \pm 5 \mathrm{mg} / 100 \mathrm{ml}(P<0.01)$. However, at all ages studied the serum glucose concentrations of the SL animals were significantly higher than in the LL animals $(P<0.05$ in all three age groups).

In contrast to the glucose levels there was a decrease of serum insulin concentration with age in both SL and LL rats (also shown at zero time in Figs. 2-4). In the SL animals the IRI levels declined from $3.7 \pm 0.9 \mathrm{ng} /$ $\mathrm{ml}$ at two days of age to $1.2 \pm 0.2 \mathrm{ng} / \mathrm{ml}$ in the four days old rats $(P<0.05)$. The corresponding values in the LL animals were $2.3 \pm 0.4 \mathrm{ng} / \mathrm{ml}$ and $1.1 \pm 0.2 \mathrm{ng} /$ $\mathrm{ml}(P<0.01)$. Throughout the observation period somewhat higher IRI levels were recorded in the SL animals, but in no case was this difference statistically significant. 
Effects of glucose administration in vivo

In the two day old rats intraperitoneal glucose administration caused almost identical serum glucose curves in the two groups of animals (Fig. 2). By contrast, the insulin response to the glucose load differed conspicuously in the two groups of animals. In rats obtained from the SL group a pronounced insulin response with a peak value of $29.2 \pm 6.5 \mathrm{ng} / \mathrm{ml}$ was observed after glucose administration (Fig. 2). In the LL animals the glucose injection provoked a much smaller IRI response, and only the peak value $(6.2 \pm$ $0.9 \mathrm{ng} / \mathrm{ml}$ ) recorded after $30 \mathrm{~min}$ was significantly raised above the pre-injection value $(P<0.01)$. At all post-injection time intervals studied the insulin values of the SL animals were significantly higher than those obtained in the LL animals.

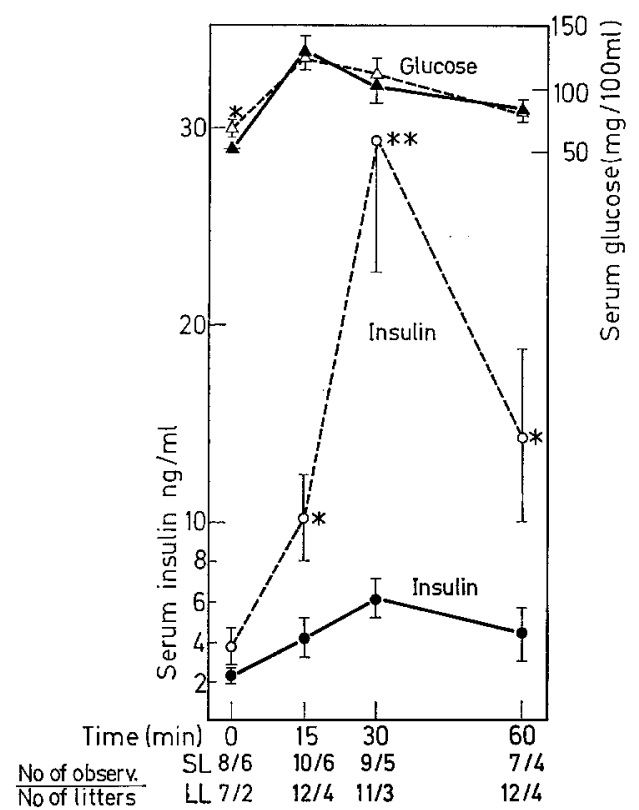

Fig. 2. Effects of an intraperitoneal glucose injection $(2 \mathrm{~g} / \mathrm{kg})$ on the serum insulin and glucose levels in two day old rats from small and large litters. Insulin levels of animals from small $(\mathrm{O} \ldots . . .0)$ and large (- - litters. Glucose levels of animals from small $(\triangle \ldots . . \Delta)$ and large (A - A litters. Mean values + SEM. The asterisks denote levels of significance calculated on the differences between the values obtained in small and large litters at each point of $\operatorname{tim} \Theta(\mathrm{x}=P<0.05 ; \mathrm{xx}=P<0.01 ; \mathrm{xxx}=P<0.001)$ The number of animals in each group $v s$. the number of litters from which they originated is indicated at the bottom of the diagram

When three day old rats were injected with glucose, the serum glucose curves were of essentially the same appearance in the two groups of animals during the first $30 \mathrm{~min}$ after injection; thereafter the SL rats showed a more rapid decline towards the pre-injection value (Fig. 3). In the SL group this glucose level was reached after $60 \mathrm{~min}$, when the values of the LL animals still remained significantly higher than the pre-injection level $(P<0.01)$. At this age, the

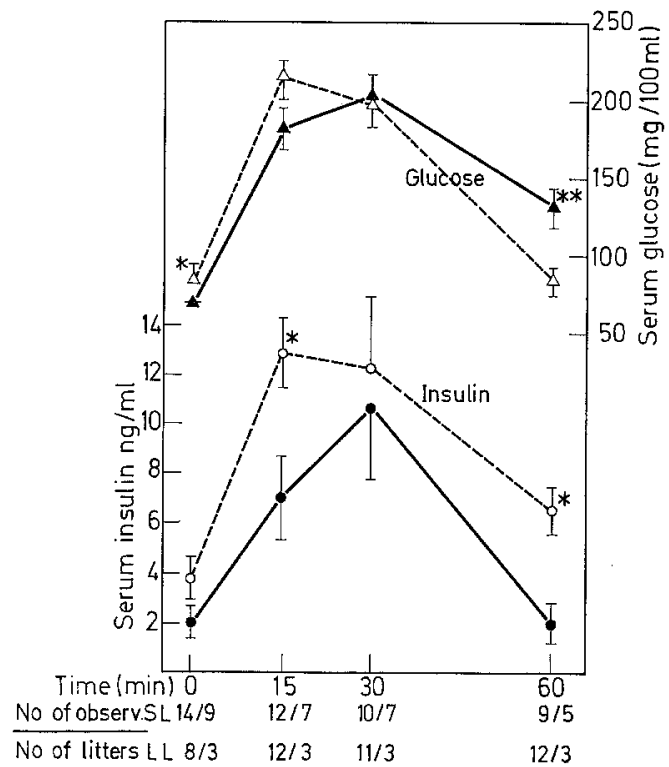

Fig. 3. Effects of an intraperitoneal glucose load on serum insulin and glucose levels in three days old rats from small and large litters. For explanation of symbols, see Fig. 2

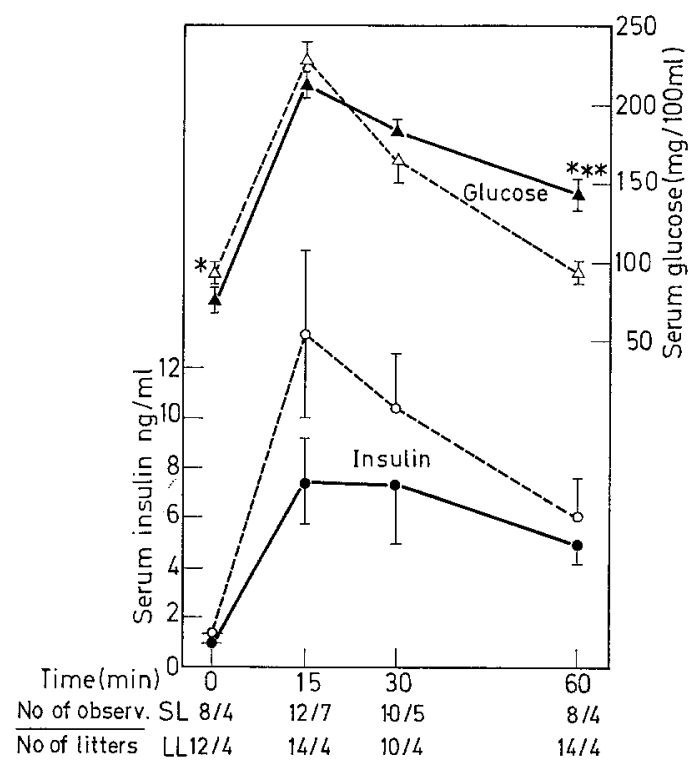

Fig. 4. Effects of an intraperitoneal glucose load on serum insulin and glucose levels in four days old rats from small and large litters. For explanation of symbols, see Fig. 2

LL animals also showed a distinct insulin response to glucose administration with a five-fold increase of serum levels after $30 \mathrm{~min}$. However, the serum insulin values of the $\mathrm{LL}$ animals were still lower than in the SL animals at all time intervals studied, the difference being significant at 15 and $60 \mathrm{~min}$ after the glucose injection (Fig. 3). Furthermore, the serum insulin curve showed an earlier peak in the SL than in the LL animals. 
Glucose administration to four day old rats caused a peak glucose level of the same magnitude in the two groups of animals (Fig. 4). While normoglycaemia was recorded $60 \mathrm{~min}$ after the glucose injection in the $\mathrm{SL}$ animals, the serum glucose curve in the LL group displayed a considerably slower decline to pre-injection levels. In the SL group glucose administration caused a distinct serum insulin peak 15 min after the injection. The samples obtained at $60 \mathrm{~min}$ still showed IRI levels significantly above the pre-injection values $(P<0.01)$. In the LL animals of the same age, the glucose injection provoked a less pronounced insulin response than that recorded in the SL rats. The IRI levels of the LL group 60 min after the injection also showed a significant elevation above the pre-injection values $(P<0.001)$.

When comparing the serum insulin curves obtained from animals of different ages, it emerged that in the two day old SL group a remarkably high insulin peak value was recorded $30 \mathrm{~min}$ after the glucose injection. In the two older age groups the peak value was lower and appeared after $15 \mathrm{~min}$. In the LL groups the peak insulin values were observed $30 \mathrm{~min}$ after the injections at two and three days of age; the increase in serum insulin levels on the second postnatal day was, however, considerably smaller than in the older LL rats. At four days of age the peak insulin value in the LL animals was also recorded $15 \mathrm{~min}$ after the glucose injection.

\section{Insulin release in vitro}

As shown in Fig. 5 the insulin output of pancreatic glands incubated at a low glucose concentration displayed small variations between animals of different ages and between animals obtained from the SL and LL groups. A stimulatory effect of a high glucose concentration in the incubation medium was recorded in the SL rats at two, three and four days of age. By contrast, the pancreatic tissue of two day old LL rats did not respond to glucose stimulation with an increased IRI secretion. At three and four days of age, however, the high glucose concentration caused a marked increase in insulin secretion.

\section{Discussion}

The present approach to the study of the development of the insulin response to glucose in newborn rats was chosen because it allowed for large differences in the caloric intake between the SL and LL animals, yet they remained in a relatively physiological environment. It has been shown that the litter size in the range observed in our delivering rats $(7-13$ per litter) has little or no influence on prenatal growth as reflected in the birth weights [8]. Any possible influence of differences in caloric supply during foetal life was, however, eliminated by random redistribution of the newborn animals into small and large litters.
During postnatal life, it is possible that the reduced access to food in the LL groups might have caused more stress reactions in these animals than in the SL groups. A lower insulin response of the LL animals to glucose might therefore merely have reflected high circulating levels of catecholamines, which are known to inhibit insulin release [12]. It may also be argued that differences in the resorption of glucose from the injection site, or in insulin removal from the circulation, could have accounted for at least some of the observations from the experiments performed in vivo. It was therefore necessary to extend the investigations to include measurements of insulin release in vitro. The results of these studies support the observations in vivo that there is a low insulin response to glucose in the two day old LL animals. In three and four day

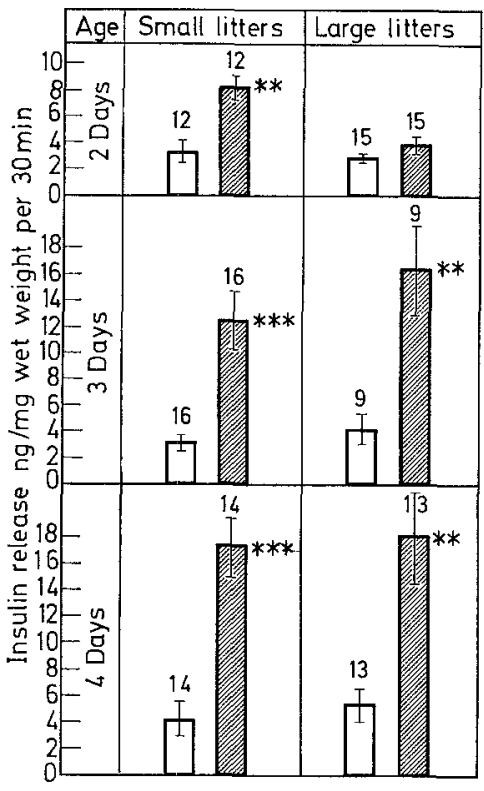

Fig. 5. The rate of insulin release in vitro from the pancreas of neonatal rats from small and large litters in the presence of glucose at a concentration of $0.6 \mathrm{mg} / \mathrm{ml}$ (open bars) or $3.0 \mathrm{mg} / \mathrm{ml}$ (filled bars). The number of observations is given at the top of each bar, which represents results from animals obtained from at least three litters. The values are not corrected for degradation of insulin during the incubation. The asterisks denote levels of significance calculated on the differences in insulin release at a low or a high glucose concentration in the incubation medium $(\mathrm{xx}=P<0.01 ; \times \times x=P<0.001)$

old rats the effects of glucose on insulin secretion were also qualitatively similar in vivo and in vitro. It therefore seems reasonable to conclude that the results obtained in the intact animals reflected variations in the pancreatic insulin release and that the low insulin response to glucose in two days old LL rats was unlikely to be caused by circulating inhibitors of insulin secretion like catecholamines.

The possibility that the delayed, and low, glucoseinduced insulin secretion in the two day old LL animals might have been due to a diminished pan- 
creatic insulin content was also considered. The present data shows a progressive increase in the total pancreatic insulin content between two and four days of age in both SL and LL animals, but the insulin content in LL animals is significantly lower than in SL animals on the second and third postnatal days. The fact that insulin release from the pancreatic B-cell of neonatal rats responds to stimuli such as tolbutamide [4], amino acids [3, 18], and glucagon plus theophylline [19] during the glucose-insensitive period also makes it unlikely that insufficient stores of insulin account for the low insulin response to glucose in the two days old LL rats. Other workers have also shown increases in total pancreatic insulin content in the first days of extrauterine life $[26,27,34]$. The values for pancreatic insulin content recorded in the present study correlate well with the levels reported by Lambert [26]. The figures for pancreatic weights given here, however, exceed those reported by other authors, who have used both Wistar $[9,26]$ and Sprague-Dawley rats [34]. This may partly be due to the smaller size at birth of the Wistar rat compared to the Sprague-Dawley rat $[8,36]$ or to the careful dissection technique employed in the present study.

During the first day of extrauterine life in the rat there is a rapid decline in basal serum insulin levels $[2,9]$, and this decrease continues until the fifth postnatal day [9]. The present results agree with these observations, in that a progressive fall in basal serum insulin levels between the second and the fourth postnatal day was observed in both the LL and SL groups. It was also shown that restriction of food intake, reflected in a very small weight gain of the LL animals, did not impede a gradual rise of serum glucose levels from the second to the fourth postnatal day.

In adult rats, starvation has been shown to produce an impairment of glucose-stimulated insulin secretion [21]. There is also evidence to suggest that the restoration of a glucose-sensitive insulin releasing mechanism when refeeding the starved animals on a high carbohydrate diet reflects changes in a glucose inducible enzyme system in the pancreatic B-cell [21]. In the present study the LL animals developed a glucose-sensitive type of insulin release in spite of sustained caloric restriction. Whether the moderate rise in serum glucose levels during the present observation. period is of any significance for the maturation process of the B-cells remains to be clarified since the serum glucose levels at this time are still low when compared to the values obtained prior to parturition [33] or during later postnatal development [3]. Furthermore, the proportional contribution of carbohydrates to the caloric supply is high during fetal life [13] but markedly reduced when the newborn rat becomes dependent on milk for its nutrition [15].

An alternative explanation is that the appearance of glucose sensitivity of the B-cells of neonatal rats could be due to an increased release of gut factors, some of which have been shown to be potent insulin secretagogues $[14,31]$. In a recent report Gentz et al. [17] have demonstrated a lower insulin response to intravenous glucose loading in starved piglets during the first day of life when compared to fed animals of the same age. These authors propose that gastrointestinal hormones, released upon feeding, might account for the insulin responses observed in the fed animals. However, the results presented here and in earlier communications $[2,4]$ demonstrate that the ability to respond to a glucose challenge with increased. insulin release at different stages of development is the same whether examined in vivo or in vitro. This fact suggests that the effect of feeding on the glucosestimulated insulin release from the B-cell is not mediated by the appearance of an extrapancreatic factor capable of promoting insulin secretion. This does not exclude the possibility that extrapancreatic factors could influence the postnatal metabolic differentiation of the islets [5], as they do in the liver of perinatal rats $[20]$.

There was a close resemblance of the blood glucose curves of the two groups of animals on the second postnatal day, in spite of the very different appearance of the two insulin curves. This supports the observation by Sutter et $a l$. [37] that in the rat there is a lack of sensitivity of the peripheral tissues towards the action of insulin at this stage of development. Alternatively, a large proportion of the immunoreactive insulin in blood may be made up of a biologically less active form of insulin such as proinsulin [11]. At three and four days of age, however, the more pronounced insulin response to glucose in vivo in the SL animals was accompanied by a faster rate of glucose disappearance. In the piglet there is evidence to suggest some insulin resistance on the first postnatal day [17]. However, controversy still exists on these matters, since other authors have concluded that, in the rat, the insulin sensitivity of the peripheral tissues appears already at birth $[10,33]$.

Note added in proof. After this paper was submitted for publication Sodoyez-Goffaux et al. (Diabetes 20, $586-$ 591 (1971)) reported that postnatal feeding may enhance the insulinogenic response to glucose in vitro.

Acknowledgements. This work was supported by The Medical Faculty of the University of Uppsala, The Swedish Diabetes Association, Expressens Prenatalforskningsfond, The Swedish Medical Research Council (B71-12X109-07C) and The United States Public Health Service (AM-12535). - The author is indebted to Miss Astrid Nordin and Miss Eva Törnelius for skilful technical assistance.

\section{References}

1. Adam, P.A.J., Teramo, K., Raiha, N., Gitlin, D., Schwartz, R.: Human fetal insulin metabolism early in gestation. Response to acute elevation of the fetal glucose concentration and placental transfer of human insulin-I-131. Diabetes 18, $409-416$ (1969).

2. Asplund, K.: The effect of glucose on the insulin secretion in foetal and newborn rats. In: Falkmer, S., Hellman, B., Täljedal, I.-B. (eds.): The structure and 
metabolism of the pancreatic islets, pp. $477-484$ London: Pergamon Press 1970.

3. - Unpublished observations.

4. - Hellerström, C.: Functional maturation of the pancreatic B-cell. Diabetologia 6, 617 (1970).

5. - - Glucose metabolism of pancreatic islets isolated from neonatal rats. Horm. Metab. Res. in press.

6. - Westman, S., Hellerström, C. : Glucose stimulation of insulin secretion from the isolated pancreas of foetal and newborn rats. Diabetologia 5, 260--262 (1969).

7. Baird, J.D., Farquhar, J.W.: Insulin-secreting capacity in newborn infants of normal and diabetic women. Lancet 1962 I, $71-74$.

8. Barr, M. jr., Jensh, R.P., Brent, R.L.: Fetal weight and intrauterine position in rats. Teratology $2,241-$ 246 (1969).

9. Blázquez, E., Montoya, E., López Quijada, C.: Relationship between insulin concentrations in plasma and pancreas of foetal and weanling rats. J. Endocrinol. 48, 553-561 (1970).

10. Britton, H.G., Blade, M.: The incorporation of radioglucose into glycogen in foetal and neonatal rat diaphragm in vitro: The effect of insulin. Biol. Neonate 16, $370-375(1970)$.

11. Clark, J.L., Rubenstein, A.H., Oyer, P.E., Mackenzie, J.J., Cho, S., Steiner, D.F.: Proinsulin and insulin biosynthesis. In: Falkmer, S., Hellman, B., Täljedal, I.-B. (eds.) : The structure and metabolism of the pancreatic islets, pp. 339-348. London: Pergamon Press 1970.

12. Coore, H.G., Randle, P.J.: Regulation of insulin secretion studied with pieces of rabbit pancreas incubated in vitro. Biochem. J. 93, 66-78 (1964).

13. Dawes, G.S.: Foetal and neonatal physiology, p. 210. Chicago: Year Book Publishers 1968.

14. Dupré, J.: An intestinal hormone affecting glucose disposal in man. Lancet 1964 II, 672-673.

15. Dymsza, H.A., Czajka, D.M., Miller, S.A.: Influence of artificial diet on weight gain and body composition of the neonatal rat. J. Nutr. 84, 100-106 (1964).

16. Eränkö, O.: Quantitative methods in histology and microscopic histochemistry, p. 23. Basel - New York: S. Kargers Publishers 1955.

17. Gentz, J., Persson, B., Kellum, M., Bengtsson, G., Thorell, J.: Effect of feeding on intravenous glucose tolerance and insulin response in piglets during the first day of life. Life Sci. 10, Part II, 137-144, (1971).

18. Grasso, S., Messina, A., Saporito, N., Reitano, G.: Serum-insulin response to glucose and aminoacids in the premature infant. Lancet 1968 II, $755-757$.

19. - - - - Effect of theophylline, glucagon and theophylline plus glucagon on insulin release in the premature infant. Diabetes 19, 837-841 (1970).

20. Greengard, O.: Enzymatic differentiation in mammalian liver. Science 163, $891-895$ (1969).

21. Grey, N.J., Goldring, S., Kipnis, D.M.: Evidence for a glucose-inducible glucoreceptor for insulin secretion in the rat. In: Cerasi, E., Luft, R., (eds.): Pathogenesis of diabetes mellitus, pp. 155-171. Stockholm: Almqvist \& Wiksell 1970.

22. Hales, C.N., Randle, P.J.: Immunoassay of insulin with insulin antibody precipitate. Biochem. J. 88, $137-146(1963)$
23. Hjelm, M., De Verdier, C.-H.: A methodological study of the enzymatic determination of glucose in blood. Scand. J. clin. Lab. Invest. 15, 415-428 (1963).

24. Isles, T.E., Dickson, M., Farquhar, J.W.: Glucose tolerance and olasma insulin in newborn infants of normal and diabetic mothers. Pediatr. Res. 2, 198-208 (1968).

25. Jørgensen, K.R., Deckert, T., Pedersen, L. M., Pedersen, J.: Insulin, insulin antibody and glucose in plasma of newborn infants of diabetic women. Acta endocrinol. (Kbh.) 52, 154-167 (1966).

26. Lambert, A.E.: Biochemical and morphological studies of cultered fetal rat pancreas. Thesis: Geneva and Louvain 1970.

27. - Orci, L., Junod, A.F., Jeanrenaud, B., Renold, A.E., Roullier, Ch.: Biological and morphological studies on foetal and newborn rat pancreas. Diabetologia 5, 46 (1969).

28. - - Kanazawa, Y., Renold, A.E.: Biosynthesis and release of insulin in organ cultures of fetal rat pancreas. Acta Diabetologia Lat. 6 (Suppl. 1), 505-537 (1969).

29. Mintz, D.H., Chez, R.A., Horger, E.O.: Fetal insulin and growth hormone metabolism in the subhuman primate. J. clin. Invest. 48, 176-186 (1969).

30. Mirsky, I.A., Perisutti, G., Dixon, F. J.: Destruction of $\mathrm{I}^{131}$ labeled insulin by liver slices. Proc Soc. exp. Biol. Med. 86, 228-230 (1954).

31. Moody, A.J., Markussen, J., Sundby, F., Steenstrup, C., Schaich Fries, A.: The insulin-releasing activity of extracts of the porcine intestinal tract. In: Falkmer, S., Hellman, B., Täljedal, I.-B., (eds.): The structure and metabolism of the pancreatic islets, pp. 469-476. London: Pergamon Press 1970.

32. Obenshain, S.S., Adam, P.A.J., King, K.C., Teramo, K., Raivio, K.O., Räihä, N., Schwartz, R.: Human fetal insulin response to sustained maternal hyperglycemia. Now Engl. J. Med. 283, 566-570 (1970).

33. Picon, L., Montane, M.: Glycémies foetale et maternelle chez la ratte à divers stades de la gestation. Action de l'insuline injectée au foetus sur sa glycémie. C. R. Acad. Sci. [D] (Paris) 267, 860-863 (1968).

34. Rishi, S., Golob, E.U., Becker, K.L., Shah, N.: Pancreatic insulin content of nonpregnant, pregnant and postpartum rats and the developing rat fetus. Diabetes 18, 268-272 (1969)

35. Scott, D. A., Fisher, A.M.: The insulin and the zine content of normal and diabetic pancreas. J. clin. Invest. 17, 725-728 (1938).

36. Sikov, M.R., Thomas, J.M.: Prenatal growth of the rat. Growth 34, 1-14 (1970).

37. Sutter, B.Ch. J., Félix, J.M., Sutter, M.Th., Jacquot, R, Leclercq, R.: Serum IRI and ILA during pregnancy in the rat foetus and the mother. Diabetologia $6,649(1970)$.

38. Umbreit, W.W., Burris, R.H., Stauffer, J.F.: Manometric techniques. 4 th ed., p. 132. Minneapolis: Burgess Publishing Co. 1964.

Dr. Kjell Asplund,

Histological Department,

University of Uppsala,

Uppsala, Sweden 